Список литературы:

1. Алексеев А.А. Забытый мир предков [Текст] / А.А. Алексеев. - Якутск: КИФ «СИТИМ», 1993.

2. Демонстрационный проект «Экологический соменеджмент» ресурсодобывающих, органов власти и коренных малочитсленных народов Севера [Текст]. - М., 2009.

3. Дудкин Х.И. Эвенский фольклор [Текст] / Х.И. Дудкин. - Якутск: КИФ «СИТИМ», 1996.

4. Кривошапкин А.В. Кочевье длиной в жизнь [Текст] / А.В. Кривошапкин. - Якутск: НКИ «БИЧИК», 2000.

5. Кривошапкин А.В. Земля предков [Текст] / А.В. Кривошапкин. - Якутск: КИФ «СИТИМ», 1995.

6. Марфусалов Н.Е. Традиционная культура эвенков [Текст] / Н.Е. Марфусалов. - НКИ «БИЧИК», 2005.

7. Марфусалова А.Д. Мудрость экотрадиций северян [Текст] / А.Д. Марфусалова. - Якутск: НКИ «БИЧИК», 2002.

8. Никитина Р.С., Федоров, Г.Н., Винокурова Е.И. Умение жить на Севере [Текст] / Р.С. Никитина, Г.Н. Федоров, Е.И. Винокурова. - Якутск: НКИ «БИЧИК», 2011.

9. Петрова С.М. Эвенская литература [Текст] / С.М. Петрова. - СПб.: Просвещение, 1994.

10. Романова А.В., Мыреева А.Н. Фольклор эвенков Якутии: монография [Текст] / А.В. Романова, А.Н. Мыреева. - СПб.: Наука, 1971.

11. Степанова С.Р. Словарь оленеводческих терминов эвенков Алданского района [Текст] / С.Р. Степанова. - Якутск: НКИ «БИЧИК», 2009.

12. Шаманизм как религия [Текст]. - Якутск: КИФ «СИТИМ», 1992.

13. Сайт «Юридическая антропология» - [Электронный ресурс].- URL: http://www.jurant.ru/ru/publications/reindeer_disc/olen/klokov.html

14. Оленеводство в России/ Сайт «АрктикИнфо». - [Электронный ресурс] URL: http://www.arctic-info.ru/Encyclopedia/Article/olenevodstvo-v-rossii-

15. Галкин В.С. Оленеводство/ Большая Советская энциклопедия [Электронный ресурс]. - URL: http://dic.academic.ru/dic.nsf/bse/116079/Оленеводство

\title{
Колхозное хозяйство в 1938-1941 годы на примере Якутской АССР
}

Герасимов А.Г., студент, Северо-Восточный федеральный университет, 2. Якутск

E-mail: sakhastan1@mail.ru

Научные руководители: к.и.н. Акимова В.С., стариий преподаватель Андреев А.П.

Целью данной работы, является освещение состояния сельского хозяйства Якутской АССР в предвоенные годы (1938 - 1941 гг.). Надо отметить, что этот вопрос 
недостаточно изучен и требует дополнительного исследования, в свете новых архивных данных.

Общая численность населения Якутской АССР по данным предварительной переписи 1937 года составляла 360621 человек, из них сельского - 284500 человек (153057 мужчин и 131443 женщин). Позднее, к 1940 году население вырастет до 413125 человек, из них сельского - 301561 человек [9, стр. 118-123].

В план развития народного хозяйства СССР (1938 - 1942 гг.) внесла свои коррективы надвигающая война, в ходе которого государственные ассигнования на военно-промышленный комплекс были резко увеличены, вследствие чего были сокращены расходы на сельское хозяйство.

Количество колхозов Якутской АССР к 1941 г. составляло - 1065 [3, л. 9-10] и на их долю приходилось 98,7\% всех посевных площадей. А из 1065 колхозов только 199 завершили процесс поселкования [8, стр. 177-178]. Итогом коллективизации были: общественные земли были объявлены неприкосновенными, с каждой семьи изъято в пользу государства около 1 га приусадебных земель.

В плане общего развития сельского хозяйства республики, делался упор на развитие животноводства. Общая численность скота в хозяйствах республики в 1940 г. было:

- лошадей - 19440 голов;

- крупного рогатого скота - 392715 голов;

- оленей - 196697 голов;

- свиней - 10724 голов;

- $\quad$ овец - 272 голов.

Валовой сбор хлеба в 1940 году составлял 429 тыс. ц. [4, л. 85-86].

Развивалась ветеринарная служба в республике, которая вела борьбу с заболеваниями и эпидемиями среди поголовья скота. За 1939 год было привито 148408 голов [5, л. 1].

Активно шёл процесс механизации колхозов. К началу 1941 г. в республике имелось 13 МТС, внутри которых имелось около 450 тракторов и 142 комбайна [4, л. 87].

Повышалась роль колхозного труда и вовлечение всего трудоспособного населения в производство путем установления обязательного минимума выработки трудодней в ущерб интересам оставшихся единоличников и приусадебных хозяйств. Все эти меры способствовали коллективизации и укрепляли сам колхозный строй.

Увеличение воспроизводства зерна шло по двум направлениям - за счёт повышения урожайности и за счёт расширения посевных площадей. Народный комиссариат земледелия Якутской АССР спланировал довести посевную площадь в республике к 1939 г. до 100 тыс. га по яровым культурам, многолетним травам до 0,5 тыс. га и озимой ржи до 4,5 тыс. га.

Таким образом, посевная площадь к 1939 г. была увеличена на 11,7 тыс. га, т.е. на 109,2 га (яровые культуры - 100 тыс. га, в том числе озимой ржи 9,5 тыс. га) [4, л. 85-88].

Но как оказалось, реальное положение в колхозном хозяйстве было весьма удручающим. Уменьшилось число колхозов, которые смогли выдать зерно на трудодни. Неурожай хлеба и трав в 1939 г. нанёс огромный удар по развитию сельского хозяйства. В районах с преобладающим развитием животноводства: 
Сунтарском, Намском, Усть-Алданском, Мегино-Кангаласском, Чурапчинском, Таттинском и др. колхозы республики с большими трудностями осуществили хлебопоставки, семенной и страховой фонды были не полностью осуществлены, сена местами не хватало на общественное стадо.

По сравнению с 1939 г. количество продукции животноводства (мясо и масло), которое было сдано государству, составляло 877 тыс. ц. и 948 тыс. ц.; в 1940 г. было сдано - 1317 тыс. ц. и 1908 тыс. ц., это высокий показатель [1, л.46]. Однако обратное распределение по трудодням составляло только 181 тыс. ц. и 695 тыс. ц. в 1940 г. Доходы хозяйств от животноводства уходили на возмещение семян и сена, вследствие чего доходы сильно сократились. Всё это сказалось на уборочных работах 1940 г., когда в большинстве районов республики осталось огромное количество нескошенных земель, начали убираться из-под снега копны хлеба и картофель, так как у колхозников наблюдался недостаток продовольственного запаса, что в последующем негативно сказалось на их настроениях, трудовой дисциплине и работоспособности.

К концу 1940 г. во многих районах республики хлеба для распределения по трудодням практически не осталось. Сена для скота самих колхозников также не осталось, вследствие чего им пришлось перейти на подножный корм. Доходность колхозов падала с каждым годом [2, л. 2-3].

К июлю 1941 г., после начала войны, были проведены аналитические работы по состоянию животноводства в республике. По его данным «план конепоголовья по основным районам республики был выполнен на 98,1\%. Выполнили план колхозы Амгинского, Вилюйского, Орджоникидзевского, Усть-Майского и Якутского районов. По поголовью крупного рогатого скота план был выполнен на 93,5\%. Ни один район установленного планом поголовья не достиг. Невыполнение объясняется срывом плана, наличием абортов маточного поголовья и большого падежа молодняка рождения 1941 г. Выполнение государственного плана развития свиноводства по районам Якутской АССР составило всего около 49\%. Планы были выполнены только колхозами Садынского и Усть-Майского районов, у которых поголовье свиней было незначительным. Невыполнение объясняется большим падежом молодняка, и даже среди взрослых свиней из-за нерадивого, бездеятельного отношения к содержанию и уходу за поголовьем. Государственный план развития овцеводства был выполнен на 74,1\%. Невыполнение плана объясняется плохим выращиванием молодняка, а также незаконченным окотом (родами) овец» [6, л.49-50]. В целом, невыполнение было объяснено нескольким причинами: недостаточным количеством сельскохозяйственных строений, несоблюдением зооветеринарных правил содержания молодняка, из-за неблагоприятных условий и произойдет последующий падеж вышеупомянутого молодняка. Отсюда следует вывод, что основная вина за невыполнение планов лежала на самих работниках колхозов.

Важным вопросом для колхозников в этот период была оплата труда. За 1939 1941 гг. оплата труда продолжала сокращаться. Если за 1939 г. оплата за 1 трудовой день в среднем по Якутской АССР составляла: зерна, сена, масла и денег - 0,61 кг, 12,1 кг, 4,7 грамм, 0,89 коп., к 1941 г. имелись такие показатели - 0,266 кг, 3,4 кг, 3,4 грамм, 0,67 коп. [1, л.46-47]. В итоге, общая оплата сократилась в среднем на 45\%, почти в 2 раза. В мае 1941 г. была предпринята попытка повышения дополнительной оплаты труда колхозникам по мясу и молоку. Государством были поставлены такие цены (за килограмм и литр): мясо скотское в живом весе -1 руб. 65 коп., мясо оленье - 1 руб. 32 коп., свинина 3 руб. 10 коп. и молока - 70 коп. за литр. Данная мера распространялась 
только на тех, кто выполнил все государственные обязательства и образовал все колхозные фонды (семенные, страховые и. т. д.). Районное руководство было обязано строго следить за выдачей дополнительной оплаты, и категорически не допускать переавансирования [7, стр.347-348].

Таким образом, в предвоенные годы Якутская АССР в плане сельского хозяйства являлась регионом, отдававшим приоритет развитию животноводческому хозяйству. Рассмотрев данный период, сделан вывод, что наблюдался процесс повышения планов на выпуск сельскохозяйственной продукции в ущерб интересам и экономическому благосостоянию трудящихся. Во время Великой Отечественной войны в республике разразится засуха, которая приведёт к переориентированию ряда земледельческо-животноводческих и животноводческих хозяйств в рыболовецкие артели (пример: переселение жителей Чурапчинского района в северные районы). Засуха и голод унесут большое количество жизней якутян.

Но, несмотря на трудности, колхозники проявили мужество, сознательность и патриотизм во благо Великой Победы - «Всё для фронта, всё для Победы!».

\title{
Список литературы:
}

1. НА РС (Я). Ф.55. Оп.25. Д.2. Л.46 - 49. Подлинник. Рукопись.

2. НА РС (Я). Ф.105. Оп.1. Д.22. Л.2 - 3. Подлинник. Машинопись.

3. НА РС (Я). Ф.70. Оп.69. Д.1636. Л.9. - 10. Подлинник. Машинопись.

4. НА РС (Я). Ф.55. Оп. 2а. Д.8а. Л. 85. - 88. Подлинник. Машинопись.

5. НА РС (Я). Ф.55. Оп. 17. Д.33. Л. 1. Подлинник. Машинопись.

6. НА РС (Я). Ф.55. Оп. 22. Д.4. Л. 49. - 50. Подлинник. Машинопись.

7. Республика Саха (Якутия). Гос. Собр. (Ил Тумэн). Законы. Сборник законов Республики Саха (Якутия). Т.1. Ч.1: 1921 - 1961 гг. - Якутск: Изд. «Бичик», 2002. - 740 c.

8. История Якутии: учебное пособие для вузов / А.И. Гоголев. - 3-е изд., доп. Якутск : Издательский дом СВФУ, 2015. - 292 с.+56 с. вкл.

9. Сивцева С.И. Демографическая ситуация в Якутии накануне Великой Отечественной Войны. Всесоюзные переписи населения 1937 и 1939 гг. / Сивцева С.И. // «Вестник Северо-Восточного федерального университета им. М. К. Аммосова».2013. - T.10. № 1. - С. 118-123.

\section{Христианский крест на надмогильных сооружениях якутов}

\author{
Дивдевилова Е.Н., студентка, \\ Северо-Восточный федеральный университет, \\ 2. Якутск \\ E-mail: alkatepivn@mail.ru \\ Научный руководитель: \\ к.и.н, доцент Яковлева К.М.
}

По научным публикациям и полевым материалам наблюдается разнообразие форм православного креста на надмогильных сооружениях якутов. На протяжении 